\title{
The Financial Crisis in Greece Based on the Lord Momchil Dobrev-Halachev’s “Theory of Generating of Crisis” and the Lord Momtchil Dobrev Halachev’s “Theory of Mafia”
}

\author{
Momtchil Dobrev-Halachev, Mariola Garibov \\ Scientific Research Institute Dobrev \& Halachev. JSC., Sofia, Bulgaria
}

\begin{abstract}
Lord Prof. PhD Momtchil Dobrev-Halachev developed in 2008 "Theory of generating of crisis" and in 2001
"Theory of the mafia". Based on these two theories, this paper explains the establishment of the financial crises in Greece.
\end{abstract}

Keywords: crisis, mafia, corruption, theory, finance

\section{Introduction}

In the year 2008 Lord Prof. Momtchil Dobrev developed the "Theory of generating of crisis". The theory of generating of crisis has been developed by analyzing all the relationships between countries, and analyzing the causes and consequences of crises. The theory examines all possible options for generating crises. The theory ultimately leads to the conclusion that each crisis begins on the basis of a conscious action, whether of a state, of a government, of financial circles, of a president of one or more countries, of financial actors, of the financial market, stock markets, financial institutions, private interests. All the factors triggered the crisis in Greece, the conditions of neoliberalism, globalization that helped the crisis, the conditions in Greece, the development of the public debt, its increase, the presence of corruption and mafia at the different levels of government in Greece. In the paper the real reasons are described for the start of the financial crises in Greece.

\section{Literature Review}

Dobrev, M. (2013). Theory if degree of trust. Bulukrain-MM, Sofia, BG.

Dobrev, M. (2014). Theory of the corruption and theory of the mafia. Bulukrain-MM, Sofia, BG.

Dobrev, M. (2015). Theory of generating of crises. Bulukrain-MM, Sofia, BG.

Dobrev, M. (2016). Is there a mafia in the European Commission and Union?!?! Bulukrain-MM, Sofia, BG.

\section{Research Methods}

The research methods are the analysis of the facts in Greece, the development of Greece, and the management of Greece for the last decades, the analysis of which foreign companies enter Greece, create

Momtchil Dobrev-Halachev, Ph.D., professor, Scientific Research Institute Dobrev \& Halachev. JSC., Sofia, Bulgaria. Mariola Garibova, Ph.D., professor, Scientific Research Institute Dobrev \& Halachev. JSC., Sofia, Bulgaria.

Correspondence concerning this article should be addressed to Momtchil Dobrev-Halachev, P.O. Box 101, Sofia 1404, Bulgaria. 
partnerships with state-owned companies, under what conditions and others, the analysis of the Greek realities, of neo-liberalism and globalization to accelerate a financial, economic, social, social crisis in a society and country.

\section{Analysis of the Facts About Greece}

In Greece there are all the main features of neo-liberalism-namely - the government does not interfere in the economy at all, leaving the market itself to determine the rules, and, on the other hand, the high-cost social system available —in the field of public administration in healthcare.

All the governments of Greece knew that at one point the state would not be able to service its debts. In neoliberalism, the world and domestic markets are the main driver of economic development. Different countries have different levels of economic development, and the different degree of competitiveness.

The economies of developed countries produce cheaper, produce more and better, and thus impose their output and conquer the markets of the smaller ones rather than the developed countries. This is a process of pardoning poverty. Neoliberalism raises in a natural way using the political system and political parties to impose a financial oligarchy.

The generation of the crisis in Turkey is on the basis of the burned large state debt in the social system, health and state and another administration.

Initially, ad-ministration grew from 21,000 to 200,000 . As a consequence, the administration grew to 800,000 clerks. This required a cost for this bureaucracy amounting to 14 billion a year.There is an enormous corporation and robbery.

\section{Analysis of the Basic Environments for Crisis Increase-Neo-Liberalism and Globalization}

Neoliberalism around the world leads to globalization of the world economy. There is a cyclical nature of production and crises which are preserved. Crises become increasingly honored. Crises are getting harder to overcome.

Progressive technologies are developing and there is a strategic superiority of certain states over the rest of the world.

Globalization has led to the full exploitation of small peoples by large peoples. The neolibrasylama and globalization are bringing the peoples closer, but they are actually moving away from them, and the real enslavement of one country is over others. They are approaching the near-developing countries, which makes the respective crisis immediately affect all the other countries that are in this industrial and other development. Smaller countries are affected by lagged lag and in smaller degrees.

Countries in the world are not at the same level of development, whether industrially or spiritually and culturally.

In neoliberalism, the world and domestic markets are the main driver of economic development.

Different countries have different levels of economic development, and the different degree of competitiveness.

The economies of developed countries produce cheaper, produce more and better, and thus impose their output and thus conquer the markets of the smaller ones rather than the developed countries. This is a process of pardoning poverty.

Neoliberalism raises in a natural way using the political system and political parties to impose a financial 
oligarchy. The financial oligarchy manages governments and countries respectively.

In turn, the interweaving of financial interests and politics is generating not only the financial oligarchy but also the corruption and mafia in the state at all levels. The financial oligarchy, the big corporations hold and thus the government in the elite state. In neoliberalism, there can not really be a civil encyclopedia and a robbery to control the government.

In fact, governments are creating such laws to protect certain corporate interests, support tactics, enforce and legitimate corrupt practices, enforce laws that exclude real civil society, genuinely enforce laws to legalize mafia in governments, and financial mafia. Indeed, governments are creating and adopting laws that legitimize thefts, corruption, mafia, and work in the state.

The media are conquered by certain corporations that govern governments and the state. The media really can not fulfill their function. Indeed, manipulation in favor of the financial and oligarchic mafia is done by the media, which prevents other thinking, memory, imposes corruption and the mafia as a way of livelihood, governance, organization of society. The media are heavily dependent on oligarchs and the oligarchic mafia.

The oligarchic mafia manages governments, and thus the whole states. The goal is that globalization becomes controlling-which the oligarchic mafia will not allow nikoga. There is no specialization of a particular country to compete in other countries.

\section{Necessary Specialized and Controlled Globalization}

Consumers' society is only in the interest and profitable only for developed countries. In this way, they place their goods and services in the contiguous countries for a long period of time.

\section{Analysis of the Real Reasons for the Financial Crises in Greece}

The basic process of generating a crisis in Greece is the borrowing of government debt from political mafia benefit from financial and other media which is main reason for the Greek crisis.

The goal is the privatization of the greek companies in Greece, on the basis of the "criticizing theory" of Momchil Dobrev.

The state statistics about the state debts during the different governments show the following data:

- 1974, after the fall of the junta in Greece, the New Democracy government inherited a debt of 337 million euros.

- 1981, the ND government handed over to PASOK a debt of two billion euros.

- 1989, the PASOK government handed over to the ND a debt of 32.2 billioneuros.

- 1993, the ND government handed over PASOK a debt of 75 billion euros.

- 2004, the PASOK government handed over to the Sun a debt of $€ 180$ billion.

- 2009, the ND government handed over to PASOK a debt of 300 billion euros.

- 2011, the debt is over 352 billion euros.

The state's VAT losses from street trade alone amount to more than seven billion euros per year. Military costs are about eight billion a year. These costs are increasing each year, scared by the fear of a possible war with a possible enemy. In practice, the financial mafia raises government debt by increasing the cost of arms and debt and the peoples concerned.

There are excessive state administrative apparatus. After each electoral victory of any party, the appointments in the state administrative area were between 160 and 300 thousand. Their number is over one 
million and 200 thousand.

Greece's banking system has concentrated on the bulk of Greek funds for production. Greek citizens are second in deposits in "Swiss coins". There are 16 million tourists in Greece each year. There are black currencies and black capital—uncollectible, hidden from taxes and charges.

Greece owns 2,400 large tankers and cargo ships. Greece is the world's second largest producer of sheep's milk. The first is in the production of olives, saffron, kiwi, and peaches. Greece is first in the production of niche, magnesium magnesite-1.6 million tons. Greece is second in the world with producing bentonite 1.5 million tons. Greece ranks first in the production of bauxite-2,174,000 tonnes. In Greece, there are the three largest golden hills in Europe. Stocks of oil and natural gas amounted to \$10 trillion.

Macroeconomics does not take into account what is the profit rate, whether this profit rate is invested back, and in what amount and share. All revenues and savings are treated in a variety of industries one by one. Moreover, there are schemes to lawfully conceal profits - through so-called offshore companies.

In the different industries of the economy, there are also various levels of profit. Thus, for example, in the military production sector, the profit rate ranges from $30 \%$ to $70 \%$. This is the industry with the highest profit rate. In light industry, the profit rate is about 5\%-10\%-we talk about tolling. Food industry profits vary between 15-25 percent. But also relative volume and sales of weapons and ammunition are the largest.

Here are the wrong conclusions of macroeconomics for a given state of the planet's economy. Here are the wrong conclusions about the consequences.

A distinction must be made between which sectors are state-owned and which sectors dominate private companies.

The generation of the crisis in Greece is based on the growth of the large state debt in the social system, health and state and another administration.

Initially, administration grew from 21,000 to 200,000. As a consequence, the administration grew to 800,000 clerks. This required a cost for this bureaucracy amounting to 14 billion a year. There is an enormous corporation and robbery.

The crisis in Greece also involved major corruption and robbery, as well as the oligarchic mafia, which has created corrupt practices as a robbery for state property.

There is political corruption that works in this direction, creating a tremendous public debt, and then certain financial environments from abroad to privatize the riches of Greece.

In Greece, different German companies and corporations are imposed on political grounds. These same companies are imposing corrupt practices. It is no accident that German companies and the German state hold the bulk of Greek debt. From the above lines, we have seen repeatedly that Greece is a very rich country. The largest chains of hypermarkets, Praktiker, Ikea, Liddel, Carrefour and others over 160 million euros a week leave Greece. Small and medium-sized manufacturers are being destroyed.

From the above lines, we have seen repeatedly that Greece is a very rich country.

The largest chains of hypermarkets, Praktiker, Ikea, Liddel, Carrefour and others over 160 million euros a week leave Greece. Small and medium-sized manufacturers are being destroyed. This leads to a gray economy.

Prices are twice as high as those in Brussels and Strasbourg than in Greece. German companies are interested in privatizing state-owned Greek firms whose assets are worth hundreds of billions of dollars at 10 times lower prices, proving the long-handed political mafia, which was aimed at privatizing Greece's assets, 
mostly by German and American companies.

The interests of other countries, for example, France, are in trade deals and, most importantly, in arms deals. The mafia is at an international level.

\section{Analysis of the Purpose of the Financial Crises in Greece-Acquisition of the Government Assets of Greece by Foreign Companies, Financial Mafia}

For this purpose, political and financial mafia works both from abroad and in Greece itself. The whole process is driven by these circles-the political and financial mafia, which includes corporate interests.

The aim is to involve Greece in a state debt crisis, with the result that the assets of the whole country are from foreign companies.

\section{Analysis of Available of Corruptia and the Mafia in Greece}

There are the elements of Momtchil Dobrev's "theory of the mafia” and the political model of mafia in Europe and for example in Greece.

In this part we will consider the basic elements, the relationships in the theory of mafia seen in the last 20 years in the experience of the authors in connections of the given situation in the state of Greece. The described below is the short description of the theory of the mafia with the vision of the authors for creating the theory of the mafia, its building and life related to the crises in Greece.

Behind the basic elements of the theory of the mafia, concrete appearances also are described. Elements of the theory of the mafia are the following:

(1) Structure of the mafia. It includes structures that depend on the formula of the mafia.

(2) Structural subordination. This is available also for the outside structure most described as organizational criminal group, also for the inside structure - this is a structure of state power, executive power, justice power.

This subordination is boss-employment. The hierarchy is strong and the obligations are executed from the top to the bottom, without comments.

(3) Functional subordination. This type of subordination of members, and others is valid also for the inside structures - the structures in the state, justice etc, also for the outside structure-mostly in mafia structures.

The structures of the mafia are: outside structure-for the criminal groups, and inside structures-for the state, justice, execution power.

(4) Connections. There are some types of connections between these structures - the inside and the outside which are the structures of the mafia.

There are connections between outside structures, connections between inside structures, connections between inside and outside structures.

The availability of the mafia action is the condition of availability of order/the order will be executed based on:

- subordinations-structural and functional.

- benefit cooperation-inside and outside.

Types of the mafia include inside juridical mafia, inside prosecutor mafia, mafia in the state, mafia in the municipilities, outside prosecutor mafia, outside juridical mafia, outside state mafia. There are procedures of taking in law orders of the mafia in the court, prosecutor office, state etc. 


\section{Formula of the Mafia}

The simplest model of the mafia which describes the factors which influence about the amount, type etc., of the mafia is the following:

MAFIA = Power/state etc. + Influence + Connections + Interests + Order/orders + Mafia structure (Inside or outside) + Monopolity rights + Laws/rules/practices/procedures + Possibility of taking an alternative decision - Obligation - Responsibilities - Morality/ethics.

The mafia is available also for the public and private sector. The power of the mafia and the corruption practices in Greece in the public sector are very stark.

The mafia process is the interaction of the presence of order between the members of the inside structure and group - this is indicated as criminal group, outside structure and members-representatives of inside structure-for example state structure or member of the state structure-from the state power, juridical power etc. All the participants are interested in the execution of the order.

The motivation of the mafia behavior is also the execution of the functional subordination and the structural subordination with the purpose of benefits such as material and non-material benefits.

The motives of the mafia behavior of members of the state public sector in Greece-such as juridical, state, etc. sector is based on the wishes of prosperity in the structure, the money and also in the functional level also in the material level. These motives are supported from some conditions for the personal public sector as massiveness of corruption practices, corruption procedures, absence of legal channels for material and non-material prosperity, impunity of intruder, possibilities for alternative solutions, fear, concrete pressure etc.

Some of the typical motives are: realization of benefits for each economic operation for each member of the action, realization of personal material benefits/for the magistrates, prosecutors, evidence of responsibilities, using of inaccuracy in the judge practice.

The mafia price is the material or non-material benefits of members of the above mentioned structures. Here is the connection between the mafia and the corruption.

\section{Sphere Spread of the Mafia in Greece}

The mafia in Greece can be found in all the spheres of the public life.

Sphere of appearances of the mafia: 1) In the state administration; 2) In the politics; 3) In the justice system; 4) In the police, prosecutor; 5) In the public services; 6) In the private sector; 7) In the TV, radio, television, newspaper, etc.; 8) In the citizen sector. All these sectors are available in Greece.

\section{Analysis of the Model of Political Mafia in Greece}

The foundation of this operating model of political mafia principle is appointed by the mafia that controls a state, ministers, civil servants and others who have data and evidence of wrongdoing in their field of work, crimes in which they have passed each other and one of the mafia has helped them to pass.

These are different cases such as gross violations of tax legislation-tax evasion, concealment of profits, tax evasion, and others-i.e. held by the officers of the NRA and accordingly entered into force the decisions of the NRA, which crimes in the penal code-various offenses under the criminal code under which the pre-trial proceedings were discontinued.

Hidden sexual orientation—Family with children with hidden sexual orientation. 
Political mafia based on just these basic as understanding is the following:

- I have appointed and appoint the family, the people in state structures.

- Preparation of contracts from the eligibility of candidates and requirements of the candidates so close candidate of the party man, to win the contract.

- Preparing the procurement of the conditions, so that only candidate middle party man can win this contest, auction, or other contract.

Political mafia mainly adopts such laws that they do not pursue relevant leaders of state structures, institutions and others. This is the guarantee of the political mafia. It creates laws to make in law violations and their crimes. To legitimize their crimes, and no problems with the justice system - the courts, prosecution, it should be political mafia to appoint their relatives chief prosecutor for prosecutors at all levels and in all offices across the country. Political mafia is appointed to positions of responsibility in the judiciary and judges loved ones to party mafia leadership positions. Of leadership positions in the courts-people close to political mafia are appointed as the final authority. This avoids any complaints of crimes committed by people of political mafia in the entire state. It is done at all levels of prosecution. Expressly legislate to not pursue commitment by prosecutors and judges crimes mentioned in the constitution if republic accepted that members do not pursue the commission of offenses by judges and prosecutors. This legitimized lawlessness, corruption, mafia. In the judiciary judges are appointed to serve only orders to give a judgment in favor of our person, our company. The theft of factories, companies is actually legitimized by the court and the prosecution.

By the court the prosecution is done so that the right people, the right companies mafia in the lists of creditors are claimants and others.

By being anywhere law acompany or person can not lead a lawsuit against prosecution for its inaction on the reluctance to reveal crimes committed by notaries, the judges prosecutors of companies close to the mafia who steal targets companies with assets worth billions. This is done by pressure from internal services-police, agents, government officials, and officials of the National Revenue Agency, tax offices, municipal offices.

Accepting such laws if there is an order from the mafia to tax and other authorities, including police, the individual can not complain of any institution, structure and you state institutions.

Just political mafia secures not only institutions, government, municipal racketeering and extortion, pressure, squeezing, extortion of embarrassing, but persecution by such institutions can only be withdrawn illegally by ownership of honest people and companies.

Political mafia in Greece works with financial institutions-banks, insurance companies, pension funds and others. There are also laws that serve the interests of these financial behemoths-banks, insurance companies, agencies, tax authorities and others. Through these financial institutions and laws to be adopted in their favor, using even the structure of enforcement, thus stealing property owned-companies, factories and others on the "inconvenient" individuals and companies, which does not enter and is not willing to give and transfer property ownership, he is pursued by illegal means as political mafia use any structures-prokurori to raise absurd accusations that prosecutors themselves to commit crimes against civilians just to perform the contract Mafia. If the IRS can not achieve this pressure and racketeering, which leads to a positive result of the mafia, it includes not only prosecutors to raise illegal and absurd accusations in making overt crimes. In extreme cases state structures are activated-police and specific individuals to perform the contract-the murder of the "inconvenient" individuals.

To ensure to conceal the actions of the mob that is secured in addition to laws and institutions, employees 
in all institutions should "inconvenient" or state court, but they provide their possession and control of the media.

Based on this theory of the mafia all the processes made in Greece are made by the mafia.

\section{Conclusions}

The basic process of generating a crises in Greece is the borrowing of government debt from political mafia benefit from financial and other media which is main reason for the Greek crisis.

The goal is the privatization of the Greek companies in Greece, on the basis of the "criticizing theory" of Momchil Dobrev.

When certain actions and resolutions certain governments in a country increase injustice, without a specific objective of economy, efficiency, public debt for the benefit of financial environments, certain states and their governments, certain manufacturing companies and others who have clear and proven interest in the privatization of state assets at undervalued prices, this leads to a deep, irreversible, financial crisis, which affects all circles in a society, economic, administrative health, pension, tax, social, demographic.

All these actions are conscious and incited to the interests of financial interests of statesmen, politicians, political parties.

\section{References}

Dobrev, M. (2013). Theory if degree of trust. Bulukrain-MM, Sofia, BG.

Dobrev, M. (2014). Theory of the corruption and theory of the mafia. Bulukrain-MM,Sofia, BG.

Dobrev, M. (2015). Theory of generating of crises. Bulukrain-MM, Sofia, BG.

Dobrev, M. (2016). Is there a mafia in the European Commission and Union?!?! Bulukrain-MM, Sofia, BG. 